\title{
The Study of the Main Indicators of the Local Environmental and Economic System "Industrial Enterprise-Environment"
}

\author{
Vladimir Mikhailov, ${ }^{1,}$, Vyacheslav Karasev², and Gennadiy Mikhailov ${ }^{3}$ \\ ${ }^{1}$ T.F. Gorbachev Kuzbass State Technical University, Department of Production Management, \\ 650000 Kemerovo, 28 Vesennya st., Russian Federation \\ ${ }^{2}$ T.F. Gorbachev Kuzbass State Technical University, Department of Mining, 650000 Kemerovo, 28 \\ Vesennya st., Russian Federation \\ ${ }^{3}$ T.F. Gorbachev Kuzbass State Technical University, Department of Energy and Resource Conserv- \\ ing Processes in Chemical and Oil and Gas Technologies, 650000 Kemerovo, 28 Vesennya st., Rus- \\ sian Federation
}

\begin{abstract}
The coal mining enterprise is a high-tech complex, which at the same time exerts all kinds of negative impact on the environment (emissions of pollutants into the air, wastewater discharges, production and consumer waste disposal). To improve environmental safety, it is necessary to study the local environmental and economic system and its main elements in order to improve managerial efficiency. The known approaches to the definition and the features of local environmental and economic system functioning are analyzed in the article. The directions for improving the efficiency of local eco-economic "industrial enterprise-environment" system management were developed on the basis of the synthesis of the study of theoretical developments of domestic and foreign researchers and the analysis of factual data. The work done is of practical importance for large industrial enterprises that exerts a diversified negative impact on the environment for preparing to the efficient sustainable managerial decisionmaking.
\end{abstract}

\section{Introduction}

Coal mining is one of the most hazardous sectors of the real economy, which is associated with a wide range of negative impacts on all elements of the environment $[1,2]$. The enhancement of national environmental legislation and international requirements [3] motivate coal producers to use innovative modern technologies, which are called BAT (best available technologies). Despite the intensification of this activity, coal mining enterprises are a potential source of high environmental and economic risks, which requires an increase in efficiency and diversification of the management methods used. In such conditions, it is advisable to create a local environmental and economic system and its main elements (the enterprise that is the source of the negative impact, the control center and the environment). To implement

\footnotetext{
*Corresponding author: mvg.eohp@,kuzstu.ru
} 
the proposed approach to management, it is necessary to identify the most significant environmental and economic aspects of the negative impact and to assess them using the developed system of environmental and economic indicators. For large industrial enterprises carrying out a complex of basic, auxiliary and servicing technological processes, the problem of various production and consumer waste generation, differentiated according to hazard classes and types, physical, chemical and other characteristics, is topical. Therefore, it is advisable to study the local environmental and economic system "industrial enterprise - environment" emphasizing this type of negative impact.

\section{Materials and Methods}

The object of the research is coal mining enterprise as a source of emission of all kinds of negative impact on the environment (emissions to atmospheric air, discharges to water sources, production and consumer waste generation).

The subject of the research is the system of basic indicators of the local environmental and economic system "industrial enterprise - environment".

The study is based on the analysis of domestic and foreign literary sources on the issues of environmental and economic system functioning and the use of adequate indicators for its evaluation. Particular attention is paid to the study of the methods for calculating the environmental and economic indicators associated with the dynamics of waste flow stream and its use. With the purpose of practical implementation of the proprietary methodology, statistical processing of environmental data of the coal mining enterprise was carried out on the basis of official reporting forms. The work also used the elements of system analysis and the results obtained by specialists of environmental and economic system management and the methodology for its analysis.

\section{Results and Discussion}

There are many scientific points of view to the definition of the concept of environmental and economic system, the management methods used, the structural features that depend on the industry specific nature of the enterprise and other factors [4-8].

For this work, the most relevant is the study [9], in which a structural diagram of environmental and economic system of a mining enterprise is presented. The authors also show a possible transformation of the environmental and economic system to a socio-eco-economic system as a complex hierarchical entity that has a certain freedom of activities and represents a single organizational structure, subsystems of which are interrelated and function together to achieve a common goal.

The study of such a specific environmental and economic system shows that in the conditions of the depletion of deposit reserves and for the purpose of full employment of mineral resources, the production intensification is the most adoptable if it includes:

- reduction of losses and dilution;

- exploitation of previously written-off and off-balance reserves;

- increase of recovery factor in coal processing, and others.

The authors of $[7,8]$ identify the main impact objectives of local environmental and economic system, in which capacity an industrial enterprise can be considered:

- reducing a company's environmental impact and reducing the environmental accident risks;

- reduction of financial losses as a result of negative impact on the environment;

- increase in the competitiveness of an enterprise.

In the same study, the mechanism for managing environmental and economic system was proposed and the deterministic management objectives were identified: 
- minimizing the difference between the use and the reproduction of resources;

- maximizing the quality of the habitat;

- improving the economic efficiency;

- reducing the nature intensity of production.

In the conditions of the region of environmental concern with a developed coal mining industry, the efficient management of the local environmental and economic system "Industrial enterprise - environment", the simplified management scheme of which is shown in Fig. $1[4,10-12]$, seems to be relevant.

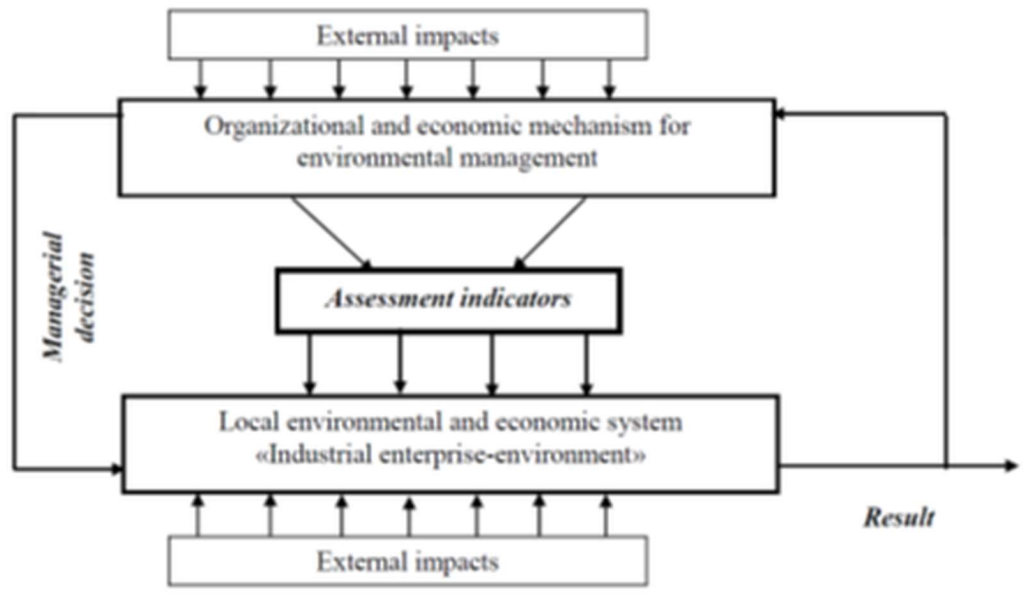

Fig. 1. Simplified scheme of the local environmental and economic system management mechanism.

From Fig. 1 it can be seen that the key element of the presented scheme of the local ecological and economic system management mechanism is the organizational and economic mechanism for environmental management [12], which has an impact on the environmental and economic system, including through the assessment indicators presented in Table. 1.

Table 1. The main environmental and economic indicators of the enterprise JSC "SUEK-Kuzbass" C.M. Kirov mine

\begin{tabular}{|l|c|c|c|c|c|}
\hline \multicolumn{1}{|c|}{ Indicator } & $\mathbf{2 0 1 3}$ & $\mathbf{2 0 1 4}$ & $\mathbf{2 0 1 5}$ & $\mathbf{2 0 1 6}$ & $\mathbf{2 0 1 7}$ \\
\hline $\begin{array}{l}\text { Economic damage from pollution of } \\
\text { water sources, mln. rubles }\end{array}$ & 143.89 & 60.49 & 4.72 & 6.30 & 6.39 \\
\hline $\begin{array}{l}\text { Economic damage from air pollution, } \\
\text { mln. rubles }\end{array}$ & 0.36 & 0.41 & 0.38 & 0.43 & 0.47 \\
\hline $\begin{array}{l}\text { Economic damage from production } \\
\text { and consumer waste disposal, mln. } \\
\text { rubles }\end{array}$ & 13.23 & 13.23 & 16.13 & 19.04 & 20.25 \\
\hline $\begin{array}{l}\text { Economic damage from environment } \\
\text { pollution, mln. rubles }\end{array}$ & 157.48 & 74.13 & 21.23 & 25.77 & 27.11 \\
\hline Total pollution charge, mln. rubles & 7453.4 & 7813.3 & 7061.0 & 6970.0 & 4553.0 \\
\hline
\end{tabular}

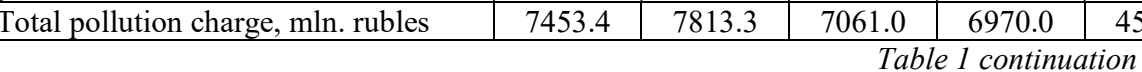

\begin{tabular}{|l|c|c|c|c|c|}
\hline \multicolumn{1}{|c|}{ Indicator } & 2013 & 2014 & 2015 & 2016 & 2017 \\
\hline $\begin{array}{l}\text { Total excess pollution charge, mln. } \\
\text { rubles }\end{array}$ & 949.3 & 1432.1 & 266 & 0 & 0 \\
\hline Excess pollution charge ratio, \% & 12.74 & 18.33 & 3.77 & 0 & 0 \\
\hline Environmental fine ratio, \% & 4.73 & 10.54 & 33.25 & 27.05 & 16.79 \\
\hline $\begin{array}{l}\text { Volume of production (coal mining), } \\
\text { kt }\end{array}$ & 3747 & 4198 & 4668 & 5720 & 7177 \\
\hline
\end{tabular}




\begin{tabular}{|l|c|c|c|c|c|}
\hline $\begin{array}{l}\text { Coal mining damage intensity, RUB } \\
/ \mathrm{t}\end{array}$ & 41.99 & 17.65 & 4.55 & 4.51 & 3.78 \\
\hline Coal mining charge intensity, RUB /t & 1.99 & 1.86 & 1.51 & 1.22 & 0.63 \\
\hline
\end{tabular}

From Table 1 it can be seen that the magnitude of economic damage from the environmental pollution during the period under review has significantly decreased from 157.48 million rubles in 2013 to 27.11 million rubles in 2017. Such a situation in 2013 is caused by the large value of the economic damage from pollution of water sources (143.89 million rubles). If we consider single elements of the environment, the maximum decreasing change is observed for the economic damage from pollution of water sources. The economic damage from air pollution fluctuates approximately on the same level from 0.36 million rubles up to 0.47 million rubles. The negative trend of gradual increase in the economic damage takes place in the production and consumer waste, which requires a more detailed analysis of this problem. The analysis of the pollution charge shows that it changed insignificantly until 2016 (from 7.45 million rubles to 6.97 million rubles), after which there was a sharp decline in $2017-4.55$ million rubles. The excess pollution charge and its ratio in the overall charge value change "non-linearly" - an increase in 2014 compared to the previous period, respectively, by 482.8 thousand rubles and by $5.59 \%$ and further decline of both indicators to 0 in 2016 and 2017.

To study the environmental and economic system, the environmental fine ratio, which shows how the pollution charge fulfills its compensatory functions, is of great importance. This indicator increased significantly in 2015 to $33.25 \%$ and is $16.79 \%$ in 2017 , which, on the one hand, positively characterizes the enterprise's environmental policy; on the other hand it reflects the deterioration of the positive trend.

An increase in the adequacy of the assessment can be achieved with the help of relative indicators, such as coal mining damage intensity and charge intensity. The damage intensity, characterizing the magnitude of economic damage per 1 ton of coal produced, has a maximum value of 41.99 rubles per ton in 2013, after which a sharp decline of the indicator to 3.78 rubles / ton begins. Another relative indicator is charge intensity, which shows the amount of pollution charge also per 1 ton of coal mined. Here, a similar situation of the decrease in the value of the indicator from 1.99 rubles per ton in 2013 to 0.63 rubles per ton in 2017 is observed. The conclusion on the dynamics of relative indicators is consistent with the interpretation of the environmental fine ratio adjusted for the data of 2017.

The considerable increase in economic damage from the production and consumer waste disposal considered above requires detailed analysis of this type of negative impact. For this purpose, Fig. 2 shows the dynamics of specific waste generation.

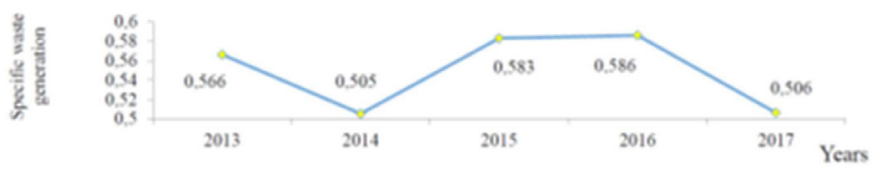

Fig. 2. The dynamics of specific waste generation of the enterprise JSC "SUEK-Kuzbass" C.M. Kirov mine, kt.

The dynamics of specific waste generation, characterized by the mass of waste per 1 ton of coal production, reflects a non-linear tendency to the indicator increase to $0.583 \mathrm{kt}$ and $0.586 \mathrm{kt}$ in 2015 and 2016 and subsequent decline to $0.506 \mathrm{kt}$ in 2017 (Fig. 2).

The efficient functioning of local environmental and economic system of coal-mining enterprise can be implemented on the basis of the algorithm for managing production and consumer waste in terms of their internal and external utilization. In Table 2 the system of indicators of production and consumer waste is shown, the calculation of which is based on the proprietary methodology [13]. 
Table 2. Dynamics of the main ecological and economic indicators of production and consumer waste of JSC "SUEK-Kuzbass" C.M. Kirov mine

\begin{tabular}{|l|c|c|c|c|c|}
\hline \multicolumn{1}{|c|}{ Indicator } & $\mathbf{2 0 1 3}$ & $\mathbf{2 0 1 4}$ & $\mathbf{2 0 1 5}$ & $\mathbf{2 0 1 6}$ & $\mathbf{2 0 1 7}$ \\
\hline $\begin{array}{l}\text { Internal waste utili- } \\
\text { zation ratio }\end{array}$ & $3.12 \cdot 10^{-4}$ & $3.26 \cdot 10^{-4}$ & $1.37 \cdot 10^{-4}$ & 0.0014 & 0.0012 \\
\hline $\begin{array}{l}\text { Internal waste } \\
\text { neutralization ratio }\end{array}$ & 0 & 0 & 0 & 0 & 0 \\
\hline Waste import ratio & 0 & 0 & 0 & 0 & 0 \\
\hline Waste export ratio & 1.051 & 1.117 & 1.000 & 0.999 & 0.999 \\
\hline $\begin{array}{l}\text { External waste utili- } \\
\text { zation ratio }\end{array}$ & 0.899 & 0.999 & 0.999 & 0.998 & 0.999 \\
\hline $\begin{array}{l}\text { Internal waste dis- } \\
\text { posal ratio }\end{array}$ & 0 & 0 & 0 & 0 & 0 \\
\hline $\begin{array}{l}\text { External waste dis- } \\
\text { posal ratio }\end{array}$ & $3.55 \cdot 10^{-4}$ & $3.71 \cdot 10^{-4}$ & $4.49 \cdot 10^{-4}$ & $3.22 \cdot 10^{-4}$ & $2.62 \cdot 10^{-4}$ \\
\hline
\end{tabular}

From Table 2 it can be seen that the internal waste utilization ratio, characterizing the level of its independent use, has low values for the entire study period, but a positive trend of increase in 2016 and 2017.

The ratios of internal waste disposal, waste import and internal waste disposal have zero values and show the presence of the following trends:

- poorly developed waste disposal facilities of the enterprise;

- absence of "external" waste coming from third-party enterprises;

- lack of engineering capabilities of disposal of waste from internal and external sources on its own operated facilities (production areas, disposal sites).

The waste export ratio reflects the ratio of the waste mass sent to other enterprises and the amount of own waste generated during the reporting period. The significant values of this indicator, especially in 2013 and 2014, characterize the existence of a stable trend of waste transfer to other economic entities. This conclusion is confirmed by the significant value of the external waste utilization ratio, showing the ratio between the amount of waste transferred to third-party enterprises for the utilization, and own waste, including those obtained from external sources.

The final element of the simplified indicator system presented is the external waste disposal ratio as the ratio between the amount of waste transferred to third party companies for storage and disposal and own waste, including those obtained from external sources. This ratio has steadily low values in the range from $2.62 \cdot 10^{-4}$ to

$4.49 \cdot 10^{-4}$.

The analysis requires a practical application related to organizational, economic, infrastructural and technological solutions aimed at reducing the negative load, especially of production and consumer waste $[2,14,15]$.

\section{Conclusion}

The conducted research allows drawing the following conclusions:

- the analysis of known approaches to the definition and the features of local environmental and economic system functioning for the development of an adequate model of environmental and economic system of a particular coal-mining enterprise;

- a simplified scheme for the local environmental and economic system management mechanism, allowing identifying structural elements that require improvement, is constructed;

- a system of environmental and economic indicators for the assessment of local environmental and economic system, which is maximally adapted to the specific features of an enterprise, is proposed; 
- the interpretation of the considered environmental and economic indicators is carried out with a special emphasis on the characteristics of the negative impact and the direction of production and consumer waste utilization;

- the main directions of improving the management efficiency of local environmental and economic system of a coal mining enterprise have been developed, which minimize the negative impact on the environment and are related, in particular, to the development of the "waste-processing" facilities of mine.

\section{References}

1. M.A. Tyulenev, S.A. Zhironkin, O.I. Litvin, E.A. Tyuleneva, O.V. Zhironkina, S.O. Markov, Geotech. Geol. Eng. 35(5), 2065 (2017)

2. N.M. Kachurin, V. I. Efimov, S.A. Vorobev, Gornyi Zhurnal, 9, 138 (2014)

3. V.M. Zolotukhin, V.A. Gogolin, M.Yu.Yazevich, M.I. Baumgarten, A.V. Dyagileva, IOP Conf. Ser.: Earth Environ. Sci., 50(1), 012027 (2017)

4. V.N. Burkov, I.V. Burkova, Game Theory and Application, 17, 17 (2015)

5. G.A Ugolnitskii, A.B. Usov, Automation and Remote Control. 70(5), 897 (2009)

6. V.M. Tumin, A.G. Koryakov, E.P. Nikiforova, World Applied Sciences Journal, 25(6), 645 (2013)

7. E.A. Tretyakova, World Applied Sciences Journal, 25(5), 756 (2013)

8. E.A. Tretyakova, Studies on Russian Economic Development, 25(4), 423 (2014)

9. O.V. Kosolapov, M.N. Ignatyeva, A.A. Litvinova, Economy of Region, 1, 158 (2013)

10. V.P. Avdeev, V. N. Burkov, T.V. Kiseleva, Automation and Remote Control, 62(10), 1645 (2001)

11. I.A. Ageev, V.N. Burkov, V.I. Zinchenko, T.V. Kiseleva, Automation and Remote Control, 66(6), 995 (2005)

12. T.V. Kiseleva, V.G. Mikhailov, G.S.Mikhailov, IOP Conf. Ser.: Earth Environ. Sci., 84(1), 012044 (2017)

13. V.G. Mikhailov, N.N. Golofastova, T.V. Galanina, T. G. Koroleva, Ya. S. Mikhailova, IOP Conf. Ser.: Earth Environ. Sci., 50(1), 012038 (2017)

14. S. Markov, M. Tyulenev, O. Litvin, E. Tyuleneva, E3S Web of Conf., 15, 01011 (2017)

15. A. Pimonov, E. Raevskaya, T. Sarapulova, E3S Web of Conf., 15, 01021 (2017) 